\title{
MODERN METHODS AND NEW TRENDS FOR FORENSIC MEDICAL ASSESSMENT OF ELECTRICAL CURRENT MARKS
}

\author{
(C) Bachinskiy V.T. ${ }^{1}$, Vanchulyak O.Ya. ${ }^{1}$, Savka I.G. ${ }^{1}$, \\ Garazdiuk M.S. ${ }^{1}$, Kozlov S.V. ${ }^{2}$, Kostenko E.Ya. ${ }^{3}$
}

\author{
Higher State Educational Establishment of Ukraine "Bukovinian State Medical University", \\ Department of Forensic Medicine and Medical Law ${ }^{1}$ \\ State Instutution «Dnipropetrovsk medical academi» ${ }^{2}$ \\ Uzhhorod National University ${ }^{3}$
}

Introduction: The widespread use of electricity both in industry and everyday life leads to relatively frequent incidents of electrical trauma including fatal cases. It is commonly known that autopsies findings in electrocution deaths are often inconclusive because of lack of specific morphological changes. Most deaths by electricity are usually caused by cardiac rhythm disorder or respiratory arrest [1], which changes is non-specific exclusively for electrocution and may overlap with findings in any case of sudden death. Thus, a local skin lesion, the so-called current mark, continues to be the most important evidence and sometimes the only sign of the influence of electrical current on the body. Specific macro- and microscopic skin changes caused by electric current can be not only reliable signs of electrocution, but in some cases may be a source of information about conductor properties, current conditions etc. Data of this type can be obtained first of all by using additional methods of examinations, in particular the qualitative elemental analysis method, which could be a reliable way to assess the chemical composition of the conductor material. Thus, using the full range of available methods of examination of skin lesion caused by electrical current can improve the capabilities of forensic medical examination of the corpses of people who died from electrical injuries.

Objective: Conduct the analysis of the possibilities of forensic medical examination of local changes in the skin that occur during the exposing to an electric current, on the basis of data from special medical literature.

Material and methods: In the research data of twenty two medico-legal reports in the cases of death of electrocution and annual reports of the Bureaus of Legal Medicine in Ukraine were analyzed. Sources of information available in electronic scientific databases, concerning the assessment of electric current mark were studied and analyzed.

Results: Deaths by electrocution still have a significant part in the structure of violent deaths. According the annual reports data of Bureaus of Legal Medicine in Ukraine percentage of death caused by the action of electrical energy in the structure of violent death is relatively constant and during the last five years fluctuates within $0.93-1.13 \%$ with total number - 1646 people killed by the electricity. Most deaths by electrocution were caused by the action of technical electricity (Tab. 1).

Deaths caused by the electric energy in Ukraine during the last 5 years

\begin{tabular}{|c|c|c|c|c|c|}
\hline Year & 2014 & 2015 & 2016 & 2017 & 2018 \\
\hline Technical electricity & 286 & 330 & 287 & 332 & 292 \\
\hline Atmospheric electricity & 25 & 24 & 27 & 22 & 2 \\
1
\end{tabular}

During the analysis of 22 medico-legal reports in the cases of death of electrocution caused by the technical electricity was found that in 14 cases one of the most significant signs confirming the death of electrocution were specific skin lesion (current marks), which origin was approved by histological examination and only in one of them method of elemental analysis and detection of local metallization were used. In four cases there were no specific traces on skin and death by electrocution was approved by non-specific changes and circumstances of death. In four other cases there was a high-voltage trauma with massive electrical burns of the body and the determination of cause of death was not difficult.

As it was said before, in cases of death from electrocution specific skin lesions and its histopathological features sometimes the most important evidence of the electric impact on the body. There are a large number of studies aimed on the establishment of specific microscopic changes in current marks compared to the thermal injuries and blunt force lesions of skin. Hystophatological changes in current marks are usually manifested as intra-epidermal and sub-epidermal separation, 
microvesicles formation and epidermal nuclear elongations [2]. Separation of epidermis is caused by the evaporation of fluid from skin tissues due to the increase of temperature of the contact electrode. At the same time, the elongation of nuclei is explained as caused by electromagnetic effect of an electrical current [3]. However, researches indicate on the presence of all described changes in both thermal and electrical injuries, and even blunt trauma, emphasizing only degree of manifestation of this signs in different cases [2]. Such, in the case of electric injuries the nuclear elongation is most pronounced, but also observed in abrasions and thermal lesions. Authors also describe some differences in the intraepidermal and sub-epidermal separation. In electric current marks intra-epidermal separation was more common and in the case of thermal injuries sub-epidermal separation was mostly observed. Other authors describe wider spectrum of microscopic changes observed when comparing electrical current marks, flame burns and blunt force injuries (abrasions) [4]. Histological findings, described in the article, were divided on three groups: epidermal. dermal and vascular changes. Such, epidermal findings included intra-epidermal and sub-epidermal separation, coagulative necrosis, elongation and streaming of nuclei, dark staining of nuclei, pyknosis of nuclei and tightly packed nuclei. The dermal changes were: coagulative necrosis, nuclear elongation, dermal collagen homogenization. Vascular changes included vascular dilatation, hemorrhage and thrombosis. According to the authors, elongation and streaming of the epidermal and dermal nuclei were observed in all three types of injuries, but in cases of electrical trauma were observed more frequently. Tightly packed and pyknotic nuclei in the epidermal cells were specific for electrical trauma but only cased by high voltage electricity and were not observed in cases of other lesions. This changes proposed by authors for differential diagnosis of high voltage and low voltage trauma. At the same time, there were not specific markers to distinct low voltage electricity impact from thermal injuries. Coagulation necrosis of the dermis and the epidermis is specific feature of electrical marcs and flame burns and obviously was not observed in tissue samples from abrasions. Thus, histophatological changes in electrical current marks can indicate the impact of electric current but sometimes could be non-specific, especially comparing lowvoltage trauma to thermal injuries.

One of the important signs of the local action of electric current could be metallization in current mark, which corresponds to the elemental composition of the metal of conductor. The metallization phenomenon can be explained the form of electrolysis when metallic ions are embedded in the skin during the transmission of electric current from the metal to the skin [1]. The metallization in electric current marks is known and studied in forensic medicine for a quite a long period of time [5]. During this research the injuries caused by metal object heated to a high temperature or exposed to alternating current were studied, and the presence of metallization was determined by an electrographic method. The metallization appeared only in the cases of electric injuries. Various methods is possible for detecting metallization in electric current marks including histochemical methods $[6,7,8]$ in particular the staining in Prussian Blue by Perl's (for iron) and Okamoto-Utamura Rubeanic acid or Timm's method (for copper). However, the detection of metallization in current marks by histological examination sometimes is a difficult task [8].

Nowadays, the most effective and promising methods of metallization detection in current marks are different methods of elemental analysis, like energy-dispersive X-ray spectrometry (EDS), which is a convenient and simple method to detect various elements in different types of samples $[9,10]$. This method shows higher ability for metallization detection in electric current marks than histochemical methods of examination. Such, during the experiment on animals divided on two groups (first with exposure of electric current during 5 seconds, second with exposure of electric current during 10 seconds) a comparative study of histological findings and the results of energy-dispersive X-ray spectrometry was performed [11]. The detection of metallization (copper) indicated by histochemical methods of examination was about $40 \%$ in each current exposure group, but high peak of copper was detected using energy-dispersive X-ray spectrometry in all skin samples of the both current exposure groups compared to the control group, which emphasizes the usefulness of elemental analysis for proving the metallization in the current marks, especially if metallization is not observed on histological examination. The energy-dispersive X-ray spectrometry method also shows high enough detection efficiency for tissues samples after preparation for histological examination in particular to paraffin-embedded tissues [12] and formalin-fixed tissues [13]. Often found the use of energy-dispersive X-ray spectrometry method in combination with scanning electron microscopy (SEM), which expand and improve the diagnostic possibilities of EDS. It has been reported that the SEM with EDS-microanalysis is a useful tool for identification of metallization and the correspondence between elemental composition in the current mark and the metal of conductor [14, 15]. Other proposed elemental analysis methods include variable-pressure scanning electron microscope with energy dispersive X-ray microanalyser [16], atomic absorption spectroscopy [17], transmission electron microscopy [14] etc. It also should be noted the possibilities of electron microscopy in detection of some ultrastructural changes of skin tissues due to electrical impact [18] which was explained to the effects produced by the rapid dehydration of the tissue or that Joule effect can act upon the filaments and contractile proteins, causing the cell deformation. However, this research needs further investigation of morphologic ultrastructural characteristics of the current mark compared to thermal burns and blunt trauma changes in skin.

CONCLUSION. In Ukraine percentage of deaths by electrocution in the structure of violent death is quite significant, relatively constant and fluctuates within $0.93-1.13 \%$. In the determination of the cause of death in case of electrocution, the investigation into current marks, especially from the histological point of view have the most significant role. Histophatological changes in electrical current marks can indicate the impact of electric current but sometimes could 
be non-specific, especially in the cases of trauma caused by low-voltage electric current. The metallization in current mark not only an important signs of the local impact of electric current, but also can help in the identification of specific object due to the corresponding the elemental composition of the metal of conductor to the qualitative chemical composition of metal particles in the electric current mark. The ultrastructural changes of skin tissues could also be helpful in the determination of electric impact, but needs further research first of all aimed on the comparison with thermal burns, blunt trauma (abrasions) and other changes in skin.

\section{Література:}

1. Saukko P, Knight B. Knight's forensic pathology. 3rd ed. London: CRC Press; 2004. Chapter 12, Electrical fatalities; p. 326-38.

2. Uzün I, Akyildyz E, Inanici MA. Histopathological differentiation of skin lesions caused by electrocution, flame burns and abrasion. Forensic Sci Int. 2008;178(2-3):157-61. doi: 10.1016/j.forsciint.2008.03.012

3. Takamiya M, Saigusa K, Nakayashiki N, Aoki Y. A histological study on the mechanism of epidermal nuclear elongation in electrical and burn injuries. Int J Legal Med. 2001;115:152-7. doi: 10.1007/s004140100250

4. Sangita C, Garima G, Jayanthi Y, Arneet A, Neelkamal K. Histological indicators of cutaneous lesions caused by electrocution, flame burn and impact abrasion. Medicine, Science and the Law. 2018;58(4):216-21. doi: $10.1177 / 0025802418776116$

5. Marcinkowski T, Wojciechowski T. Investigation on the entrance mark by electrocution. IX Congress of the Academy of Legal Medicine and Social Medicine; 1973 Sep 23-28; Rome; Abstracts of lectures; № 13.

6. Jacobsen H. Electrically induced deposition of metal on the human skin. Forensic Sci Int. 1997;90(1-2): 85-92. doi: 10.1016/s0379-0738(97)00151-5

7. Bancroft JD, Gamble M, editors. Theory and Practice of Histological Techniques. 6th ed. Philadelphia: Churchill Livingstone; 2008. 725 p.

8. Bellini E, Gambassi G, Nucci G, Benvenuti M, Landi G, Gabbrielli M, et al. Death by electrocution: Histological technique for copper detection on the electric mark. Foren Sci Intern. 2016;264:24-7. doi: 10.1016/j.forsciint.2016.03.013

9. Nakai I, editor. Practice of fluorescent X-ray analysis. Asakura-syoten; Tokyo. 2005.

10. Marguí E, Grieken R van, X-ray fluorescence spectrometry and related techniques: an introduction. New York: Momentum Press; 2013. 143 p.

11. Tanaka N, Takakura A, Miyatake N, Jamal M, Ito A, Kumihashi M, et al. Comparison of histological findings and the results of energy-dispersive X-ray spectrometry analysis in experimental electrical injury. Legal Medicine. 2018;31:203. doi: 10.1016/j.legalmed.2017.12.005

12. Takahashi M, Kinoshita H, Nishiguchi M, Nishio H. Detection of metallic elements from paraffin-embedded tissue blocks by energy dispersive X-ray fluorescence spectrometry, Leg. Med (Tokyo). 2010;12(2):102-3. doi: 10.1016/j.legalmed.2009.12.003

13. Kinoshita H, Tanaka N, Takakura A, Kumihashi M, Jamal M, Ito A, et al. Direct measurement of formalin-fixed tissue sample by energy dispersive X-ray fluorescent spectrometry (EDX) for the identification of metal deposition in a case of electrocution. Curr Study Environ Med Sci. 2016;9:8.

14. Tomita M, Ijiri I, Shimosato K, Mikami Y, Doi Y, Uehira K. A case of accidental electrocution. Identification of metallization on the electric marks with an energy dispersive X-ray microanalyzer. Nihon Hoigaku Zasshi. 1984;38(1):59-63.

15. Kamiyama S, Ikeda M. Medicolegal studies on electrification. V. Detection of metallization on the electric marks by means of electron probe microanalyzer. Jpn J Leg Med. 1980;34:35-42.

16. Kinoshita H, Nishiguchi M, Ouchi H, Minami T, Kubota A, Utsumi T, et al. The application of a variable-pressure scanning electron microscope with energy dispersive X-ray microanaliser to the diagnosis of electrocution: a case report. Legal Med (Tokyo). 2004;6(1):55-60. doi: 10.1016/j.legalmed.2003.08.006

17. Jakubeniene M, Zakaras A, Minkuviene ZN, Benoshys A. Application of atomic absorption spectroscopy for detection of multimetal traces in low-voltage electrical marks. Foren Sci Int. 2006; 161(1):36-40. doi: 10.1016/j.forsciint.2005.10.019

18. Torre C, Varetto L. The ultrastructure of the electric burn in man: a transmission electron microscopy-scanning electron microscopy study. J Forensic Sci. 1985;30(2)448-55.

\section{Referenses:}

1. Saukko P, Knight B. Knight's forensic pathology. 3rd ed. London: CRC Press; 2004. Chapter 12, Electrical fatalities; p. 326-38.

2. Uzün I, Akyildyz E, Inanici MA. Histopathological differentiation of skin lesions caused by electrocution, flame burns and abrasion. Forensic Sci Int. 2008;178(2-3):157-61. doi: 10.1016/j.forsciint.2008.03.012

3. Takamiya M, Saigusa K, Nakayashiki N, Aoki Y. A histological study on the mechanism of epidermal nuclear 
elongation in electrical and burn injuries. Int J Legal Med. 2001;115:152-7. doi: 10.1007/s004140100250

4. Sangita C, Garima G, Jayanthi Y, Arneet A, Neelkamal K. Histological indicators of cutaneous lesions caused by electrocution, flame burn and impact abrasion. Medicine, Science and the Law. 2018;58(4):216-21. doi: $10.1177 / 0025802418776116$

5. Marcinkowski T, Wojciechowski T. Investigation on the entrance mark by electrocution. IX Congress of the Academy of Legal Medicine and Social Medicine; 1973 Sep 23-28; Rome; Abstracts of lectures; № 13.

6. Jacobsen H. Electrically induced deposition of metal on the human skin. Forensic Sci Int. 1997;90(1-2): 85-92. doi: 10.1016/s0379-0738(97)00151-5

7. Bancroft JD, Gamble M, editors. Theory and Practice of Histological Techniques. 6th ed. Philadelphia: Churchill Livingstone; 2008. 725 p.

8. Bellini E, Gambassi G, Nucci G, Benvenuti M, Landi G, Gabbrielli M, et al. Death by electrocution: Histological technique for copper detection on the electric mark. Foren Sci Intern. 2016;264:24-7. doi: 10.1016/j.forsciint.2016.03.013

9. Nakai I, editor. Practice of fluorescent X-ray analysis. Asakura-syoten; Tokyo. 2005.

10. Marguí E, Grieken R van, X-ray fluorescence spectrometry and related techniques: an introduction. New York: Momentum Press; 2013. 143 p.

11. Tanaka N, Takakura A, Miyatake N, Jamal M, Ito A, Kumihashi M, et al. Comparison of histological findings and the results of energy-dispersive X-ray spectrometry analysis in experimental electrical injury. Legal Medicine. 2018;31:203. doi: 10.1016/j.legalmed.2017.12.005

12. Takahashi M, Kinoshita H, Nishiguchi M, Nishio H. Detection of metallic elements from paraffin-embedded tissue blocks by energy dispersive X-ray fluorescence spectrometry, Leg. Med (Tokyo). 2010;12(2):102-3. doi: 10.1016/j.legalmed.2009.12.003

13. Kinoshita H, Tanaka N, Takakura A, Kumihashi M, Jamal M, Ito A, et al. Direct measurement of formalin-fixed tissue sample by energy dispersive X-ray fluorescent spectrometry (EDX) for the identification of metal deposition in a case of electrocution. Curr Study Environ Med Sci. 2016;9:8.

14. Tomita M, Ijiri I, Shimosato K, Mikami Y, Doi Y, Uehira K. A case of accidental electrocution. Identification of metallization on the electric marks with an energy dispersive X-ray microanalyzer. Nihon Hoigaku Zasshi. 1984;38(1):59-63.

15. Kamiyama S, Ikeda M. Medicolegal studies on electrification. V. Detection of metallization on the electric marks by means of electron probe microanalyzer. Jpn J Leg Med. 1980;34:35-42.

16. Kinoshita H, Nishiguchi M, Ouchi H, Minami T, Kubota A, Utsumi T, et al. The application of a variable-pressure scanning electron microscope with energy dispersive X-ray microanaliser to the diagnosis of electrocution: a case report. Legal Med (Tokyo). 2004;6(1):55-60. doi: 10.1016/j.legalmed.2003.08.006

17. Jakubeniene M, Zakaras A, Minkuviene ZN, Benoshys A. Application of atomic absorption spectroscopy for detection of multimetal traces in low-voltage electrical marks. Foren Sci Int. 2006; 161(1):36-40. doi: 10.1016/j.forsciint.2005.10.019

18. Torre C, Varetto L. The ultrastructure of the electric burn in man: a transmission electron microscopy-scanning electron microscopy study. J Forensic Sci. 1985;30(2)448-55.

\section{СУЧАСНІ МЕТОДИ ТА НОВІ ТЕНДЕНЦЇ̈ В СУДОВО-МЕДИЧНІЙ ОЦІНЦ ЕЛЕКТРОМІТКИ}

\section{Бачинський В.Т., Ванчуляк О.Я., Савка І.Г., Гараздюк М.С., Козлов С.В., Костенко С.Я.}

Резюме: В статті наведено місце електротравми в структурі насильницької смерті за даними звітів бюро судово- медичної експертизи України, підкреслена важливість судово-медичної оцінки електромітки, яка і на даний час слугує одні- єю з найважливіших ознак, що підтверджує дію електричного струму на тіло та настання смерті внаслідок ураження елек- тричним струмом. Проаналізовані сучасні літературні джерела інформації та зазначені найефективніші методи встановлення наявності електроміки та судово-медичної оцінки місцевих змін в ділянці дії електричного струму.

Ключові слова: судова медицина, електротравма, електромітка, металізація, елементний аналіз.

\section{СОВРЕМЕННЫЕ МЕТОДЫ И НОВЫЕ ТЕНДЕНЦИИ В СУДЕБНО- МЕДИЦИНСКОЙ ОЦЕНКЕ ЭЛЕКТРОМЕТКИ}

\section{Бачинский В.Т., Ванчуляк О.Я., Савка И.Г., Гараздюк М.С., Козлов С.В., Костенко Е.Я.}

Резюме: В статье указано место электротравмы в структуре насильственной смерти по данным отчетов бюро 
червень, 2019 p.

судебно- медицинской экспертизы Украины, подчеркнута важность судебно-медицинской оценки электрометки, которая и сейчас про- должает служить одним из самых важных признаков действия электрического тока на организм и наступления смерти вслед- ствие поражения электрическим током. Проанализированы современные литературные источники информации и обозначены наиболее эффективные методы установления наличия электрометки и судебномедицинской оценки локальных изменений в области воздействия электрического тока.

Ключевые слова: судебная медицина, электротравма, электрометка, металлизация, элементный анализ.

\title{
MODERN METHODS AND NEW TRENDS FOR FORENSIC MEDICAL ASSESSMENT OF ELECTRICAL CURRENT MARKS
}

\section{Bachinskiy V.T., Vanchulyak O., Savka I.G., Garazdiuk M.S., Kozlov S.V., Kostenko E.Ya.}

Resume. The article indicates the role of electrocution in the structure of violent death according to the annual reports of the Bureau of Forensic Medicine of Ukraine, emphasizes the importance of the forensic medical evaluation of the electric current mark, which still continues to be one of the most important signs of the electric current impact on the body. Modern literary sources of information are analyzed and the most effective methods for determination of the electric current marks and forensic assessment of local changes in the area of electric current impact are described.

Keywords: forensic medicine, electrocution, current mark, metallization, elemental analysis.

УДК: 616-001.45:623.443.35]:677.07.001

\section{МЕХАНІЗМ УТВОРЕННЯ ПОДВІЙНОЇ ШТАНЦМАРКИ ПРИ ПОСТРІЛАХ ІЗ ПІСТОЛЕТІВ МОДЕЛЬНОГО РЯДУ «ФОРТ»}

\author{
СГуров О.М, Куценко С.В., Щербак В.В., Гладких Д.Б., Сапєлкін В.В. \\ Харківська медична академія післядипломної освіти
}

Резюме. Зважаючи на механогенез відбою для пістолетів, було обгрунтовано механізм формування подвійної штанц- марки при пострілах із пістолетів «Форт-12», «Форт-17» та «Форт-14ТП». Установлено, що подвійні відбитки утворюва- лися лише за умов пострілу в щільний притул із пістолета, спорядженого більш ніж одним боєприпасом, тобто за умов обов'язкового зворотного руху затвора. Ця ознака може бути використана при встановленні послідовності пострілів, а також вказує на спорядження пістолета більш ніж одним патроном.

Ключові слова: вогнепальні пошкодження, пістолети «Форт», постріл упритул, штанцмарка.

ВСТУП. Охорона громадського порядку виконується працівниками органів внутрішніх справ як у повсякденних умовах, так i за надзвичайних обставин, пов'язаних із затриманням озброєних злочинців, попередженням або припиненням групових порушень громадського порядку і масових безпорядків у населених пунктах $[1,2]$. Означене зумовлює випадки застосування вогнепальної зброї працівниками правоохоронних органів, зокрема, бійцями спецпідрозділів МВС України. Штатною короткоствольною зброєю підрозділів силових структур України є пістолети вітчизняного виробництва (Вінницького КНВО «ФОРТ») «Форт-12»,

«Форт-17» та «Форт-14ТП», які наразі використовуються разом із усе ще поширеним пістолетом Макарова (ПМ). 3 2014 р пістолети «Форт-14ТП» та «Форт-17» також прийняті як штатна зброя сухопутних військ України.

При дослідженні об’єктів судово-медичної експертизи (ушкоджень тіла та пошкоджень одягу) у випадках вогнепальної травми надзвичай важливим стає питання встановлення моделі вогнепальної зброї. Тому детальне вивчення особливостей вогнепальних ушкоджень при пострілах упритул має особливе та принципове значення. Саме при контактних пострілах можливо виявити відбиток дульного кінця зброї (штанцмарку), що є вірогідною ознакою пострілу впритул та за певних умов дозволяє визначити модель вогнепальної зброї. Механізм утворення типової штанцмарки є загальновідомим та пов'язаний насамперед з дією порохових газів, що відшаровують та щільно притискають підлеглі тканини до зрізу зброї, спричиняючи їх ушкодження, яке може віддзеркалити деякі конструктивні особливості зброї. Штамп-відбитки можуть характеризуватися не лише безпосереднім ушкодженням шкіри та епідермісу або пошкодженням матеріалу одягу, але й специфічним контурним відкладанням кіптяви пострілу, яке за формою може відтворювати конструктивні елементи контактної поверхні $[3,4]$.

Для з'ясування механізму утворення подвійної штанцмарки слід розглянути деякі положення внутрішньої балістики, що стосуються саме процесу пострілу та явищ, які виникають під час пострілу. Пострілом називається викидання кулі 3 каналу ствола зброї енергією порохових газів. Від удару ударника по капсулю, зачиненого в патроннику патрона, відбувається вибух ударного складу, який запалює пороховий заряд. При згоранні порохового заряду утворюється велика кількість сильно нагрітих (до $3000^{\circ} \mathrm{C}$ ) газів, що створюють у каналі ствола високий тиск на дно кулі, дно та стінки гільзи, а також на стінки ствола та затвор. Під тиском порохових газів куля зміщується 3 місця, врізається оболонкою в нарізи каналу ствола та набуває обертального руху. Куля просувається по каналу ствола, безперервно нарощуючи швидкість, та виштовхується назовні за напрямком осі каналу ствола. Унаслідок 